\title{
Intracrinology: role of the family of $17 \beta$-hydroxysteroid dehydrogenases in human physiology and disease
}

\section{F Labrie, V Luu-The, S X Lin, J Simard, C Labrie, M El-Alfy, G Pelletier and A Bélanger}

Oncology and Molecular Endocrinology Research Center, Laval University Hospital (CHUL) and Laval University, Québec, Canada G1V 4G2

(Requests for offprints should be addressed to F Labrie, Oncology and Molecular Endocrinology Research Center, Laval University Hospital (CHUL), 2705, Laurier Boulevard, Quebec, Quebec, Canada G1V 4G2; Email: fernand.labrie@crchul.ulaval.ca)

\begin{abstract}
In women and men, an important proportion of estrogens and androgens are synthesized locally at their site of action in peripheral target tissues. This new field of endocrinology has been called intracrinology. In postmenopausal women, $100 \%$ of active sex steroids are synthesized in peripheral target tissues from inactive steroid precursors while, in adult men, approximately $50 \%$ of androgens are made locally in intracrine target tissues. The last and key step in the formation of all estrogens and
\end{abstract}

androgens is catalyzed by members of the family of $17 \beta$-hydroxysteroid dehydrogenases (17 $\beta$-HSDs) while different $17 \beta$-HSDs inactivate these steroids in the same cell where synthesis takes place. To date, seven human $17 \beta$-HSDs have been cloned, sequenced and characterized. The $17 \beta$-HSDs provide each cell with the means of precisely controlling the intracellular concentration of each sex steroid according to local needs.

Fournal of Molecular Endocrinology (2000) 25, 1-16

\section{INTRACRINOLOGY}

An important finding in the field of sex steroids is that a large proportion of androgens and estrogens in men and women are synthesized locally in peripheral target tissues from the inactive adrenal precursors dehydroepiandrosterone (DHEA) and DHEA-sulfate (DHEA-S) (Fig. 1). In fact, in postmenopausal women, $100 \%$ of sex steroids are synthesized in peripheral tissues from precursors of adrenal origin except for a small contribution from ovarian and/or adrenal testosterone and androstenedione. Thus, in postmenopausal women, all active sex steroids are made in target tissues by an intracrine mechanism.

This review was presented at the Symposium on Enzymes and Steroid Hormone Action at the 19th Joint Meeting of the British Endocrine Societies with EFES, March 2000, Birmingham, UK.
The secretion of DHEA and DHEA-S by the adrenals increases during the adrenarche in children at the age of 6-8 years and elevated values of circulating DHEA and DHEA-S are maintained throughout adulthood, thus providing the high level of substrates required for conversion into potent androgens and estrogens in peripheral tissues. In fact, plasma DHEA-S levels in adult men and women are 100 to 500 times higher than those of testosterone and 1000 to 10000 times higher than those of estradiol, thus providing a large reservoir of substrate for conversion into androgens and/or estrogens in peripheral intracrine tissues.

The term intracrinology was coined in 1988 by Labrie et al. to focus our attention on the synthesis of active steroids in peripheral target tissues where steroid action is exerted in the same cells where synthesis takes place without release of the active hormones in the extracellular space and in the general circulation (Labrie 1991) (Fig. 2). The rate 


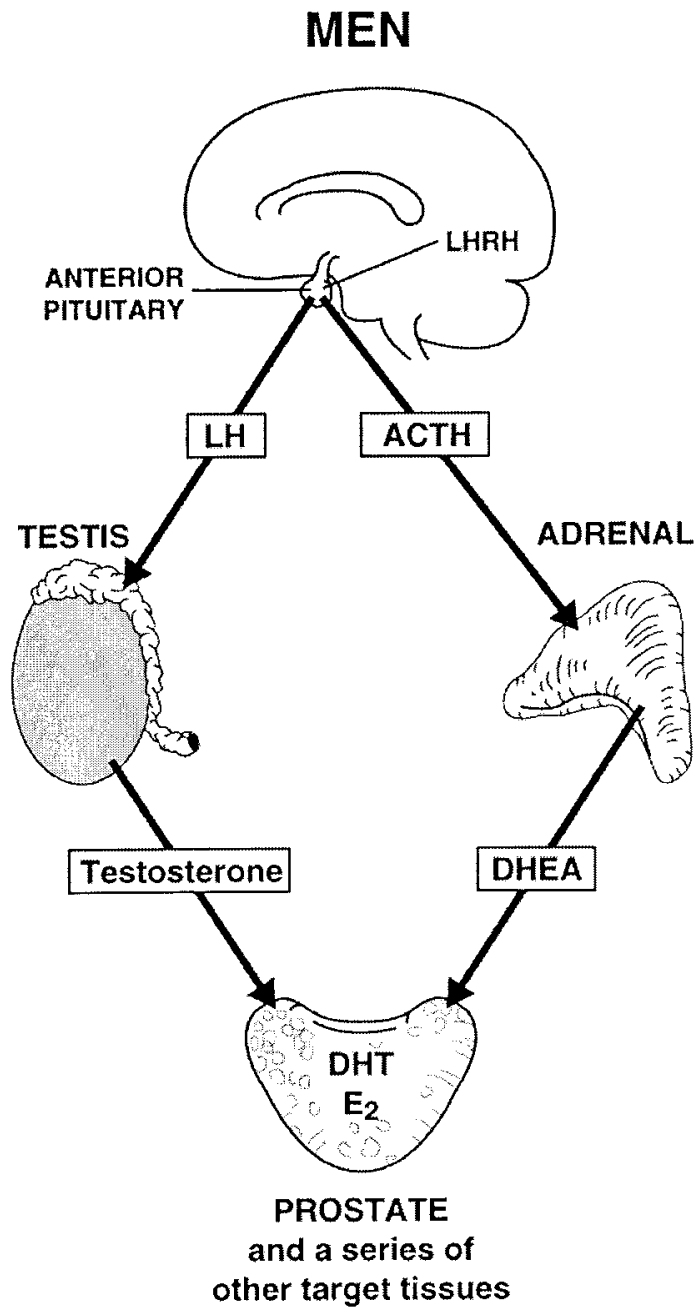

PREMENOPAUSAL WOMEN

FIGURE 1. Schematic representation of the role of gonadal (testicular and ovarian) and adrenal sources of sex steroids in men and premenopausal women. After menopause, the secretion of estradiol by the ovaries ceases and $100 \%$ of sex steroids are made locally in peripheral target intracrine tissues. LH, luteinizing hormone; ACTH, adrenocorticotropin.

of formation of each sex steroid thus depends upon the level of expression of the specific androgen- and estrogen-synthesizing enzymes in each cell of each tissue (Labrie et al. 1985a, Labrie 1991, Stewart \& Sheppard 1992, Hobkirk 1993).

It is thus remarkable that humans, in addition to possessing a highly sophisticated endocrine system, have largely vested sex steroid formation in peripheral tissues. In fact, while the ovaries and testes are the exclusive sources of androgens and estrogens in the lower mammals, the situation is very different in higher primates, where active sex steroids are to a much larger degree or wholly synthesized locally in peripheral tissues; this provides autonomous control to target tissues which are thus able to adjust the formation and metabolism of sex steroids according to local requirements (Labrie 1991). The situation of a high secretion rate of adrenal precursor sex steroids in men and women is thus completely different from the animal models used in the laboratory, namely the rat, mouse, guinea pig and all others (except monkeys) where the secretion of sex steroids takes place exclusively in the gonads (Cutler et al. 1978, Labrie et al. 1985a, Bélanger et al. 1989, Labrie et al. $1992 b$, Labrie 1993, and references therein). In these lower animal species, no significant amounts of androgens or estrogens are made outside the testes or ovaries and no sex steroids are left after castration. 

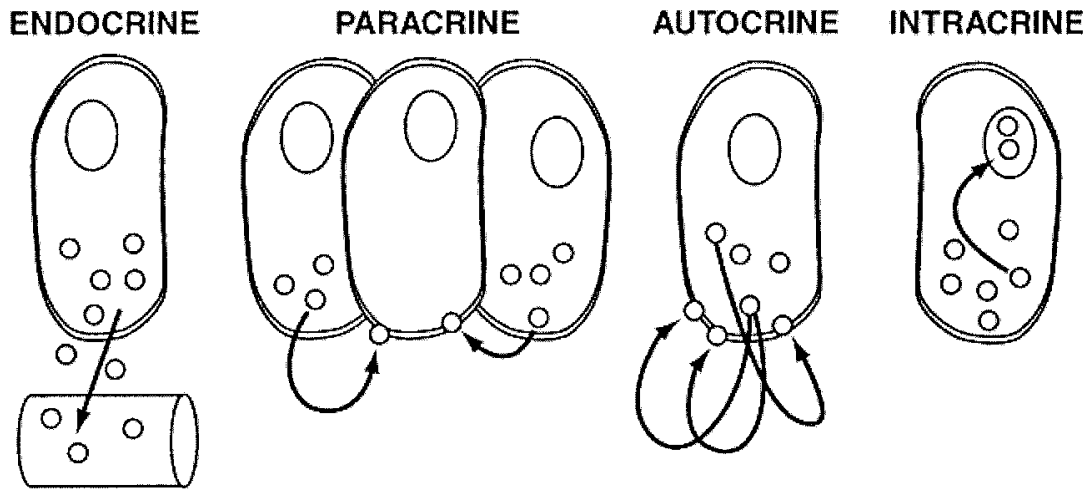

FIGURE 2. Schematic representation of endocrine, paracrine, autocrine and intracrine secretion. Classically, endocrine activity includes the hormones secreted in specialized glands, called endocrine glands, for release into the general circulation and transport to distant target cells. On the other hand, hormones released from one cell can influence neighboring cells (paracrine activity) or can exert a positive or negative action on the cell of origin (autocrine activity). Intracrine activity describes the formation of active hormones which exert their action in the same cells where synthesis took place without release into the pericellular compartment. Reproduced with permission from Labrie (1991).

\section{HOW THE ROLE OF ADRENAL DHEA AS A SOURCE OF ANDROGENS WAS DISCOVERED}

In the course of studies on the hormonal therapy of prostate cancer, a surprising observation was that approximately $50 \%$ of DHT was left in the prostate in men who had their testicles removed or had complete blockade of testicular androgen secretion following treatment with a luteinizing hormonereleasing hormone (LHRH) agonist (see Labrie et al. 1985b, 1996a for reviews). Thus, while blood levels of testosterone were reduced by $90-95 \%$ following castration, the intraprostatic concentration of dihydrotestosterone (DHT), the active intracellular androgen, was decreased by only $50 \%$, thus suggesting that, in the absence of testicles, another source continued to provide androgens to the prostate.

This crucial observation led to the development of combined androgen blockade which uses a pure antiandrogen added to medical or surgical castration. The objective is to block simultaneously the androgens of both testicular and adrenal origin at the start of treatment of prostate cancer (Labrie et al. 1982, 1985a). Combined androgen blockade was thus the first treatment demonstrated in prospective and randomized trials to prolong life in prostate cancer (Crawford et al. 1989, Caubet et al. 1997, Bennett et al. 1999, Prostate Cancer Triallists' Collaborative Group 2000). Recent meta-analyses of all the randomized studies using the pure antiandrogens, flutamide and nilutamide, show that the risk of death from any cause is reduced by $8 \%$ to $20 \%$ in men with advanced prostate cancer who received combined androgen blockade compared with castration alone (Caubet et al. 1997, Bennett et al. 1999, Prostate Cancer 'Triallists' Collaborative Group 2000). In analogy with any type of cancer, where treatment of early disease is known to be much more efficient than treatment of advanced cancer, the same combined androgen blockade applied at the localized stage of prostate cancer can even cure the disease in a large proportion of patients (Labrie et al. 1999, Labrie 2000).

On the other hand, proof of the role of estrogen formation in peripheral intracrine tissues is well illustrated in women by the important benefits on breast cancer observed in postmenopausal women treated by a series of aromatase inhibitors (Buzdar et al. 1996). Most convincingly, the recent observation that postmenopausal women who received the antiestrogen, raloxifene, for only 3 years had a $76 \%$ decrease in the incidence of breast cancer (Cummings et al. 1999) is a clear demonstration of the role of extra-ovarian estrogens in the development and growth of breast cancer.

\section{THE 17ß-HYDROXYSTEROID DEHYDROGENASES, KEY ENZYMES ACTING AT THE LAST STEP OF ANDROGEN AND ESTROGEN FORMATION}

The synthesis from DHEA of the most potent natural androgen, DHT and of the most potent 


\section{Human steroidogenic enzymes in peripheral intracrine tissues}

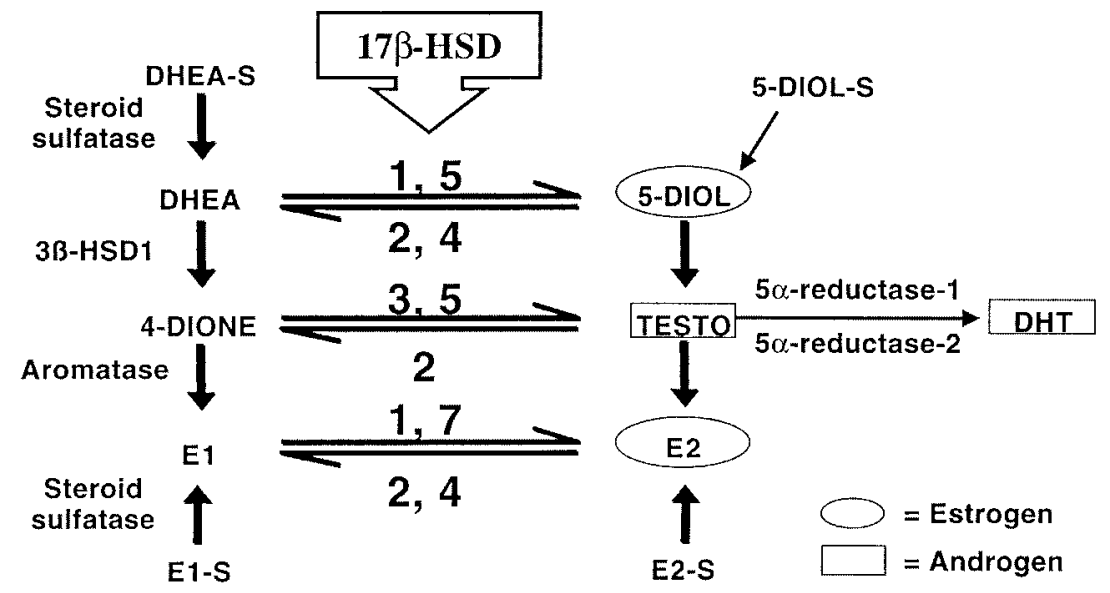

FIGURE 3. Main biosynthetic and inactivating pathways of androgens and estrogens in the human. The various types of $17 \beta$-HSDs are indicated as numbers; arrows indicate the direction of their enzymatic activity. TESTO, testosterone.

natural estrogen, $17 \beta$-estradiol $\left(\mathrm{E}_{2}\right)$ involves several enzymes, namely $3 \beta$-hydroxysteroid dehydrogenase/

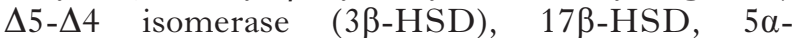
reductase and/or aromatase (Fig. 3 ).

As illustrated in Fig. 3, the enzymes of the $17 \beta-H S D$ gene family are responsible for the interconversion of DHEA and androst-5-ene-3 $\beta$, $17 \beta$-diol (5-diol), androstenedione (4-dione) and testosterone, as well as estrone $\left(\mathrm{E}_{1}\right)$ and $\mathrm{E}_{2}$. The interconversion of androstanedione and DHT as well as androsterone (ADT) and androstane $3 \alpha, 17 \beta$-diol is controlled by the same enzymes. The $17 \beta$-HSDs are therefore required for the synthesis of all active androgens and all active estrogens as well as for their inactivation.

Since the molecular structure of the key nonP450-dependent enzymes involved in sex steroid formation had not been elucidated and knowing that local formation of sex steroids plays a major role in both normal and tumoral hormone-sensitive tissues (Labrie et al. 1985a), an important proportion of the research program of many groups, including ours, has been devoted to this exciting and therapeutically promising area (for reviews see Labrie et al. 1992b, $1993,1996 b)$. It is important to mention that $40 \%$ of all cancers, namely breast, prostate, ovarian and uterine cancers, are sex steroid-sensitive and are thus prime candidates for approaches based upon control of intracrine activity.

That $17 \beta-H S D$ activity is widely distributed is illustrated by the finding that in a study of 25 tissues in the monkey, both estrogenic and androgenic $17 \beta$-HSD activities were found in all tissues examined, thus indicating the generalized role of $17 \beta$-HSDs in the formation of androgens and estrogens in peripheral target intracrine tissues (Martel et al. 1994). Estrogenic 17ß-HSD-type 1 mRNA (expression) and activity have been found in the fifteen human tissues examined (Martel et al. 1992). The highest rates of estrogenic 17 $\beta$-HSD activity were found in the placenta, liver, ovary, endometrium, prostate, testis and adipose tissue (Martel et al. 1992).

\section{Type 1 17ß-HSD}

The molecular structure of a human type 1 $17 \beta$-HSD cDNA and its corresponding gene, which encodes a predicted protein of 327 amino acids, was the first to be elucidated (Peltoketo et al. 1988, Luu-The et al. 1989, 1990, Peltoketo et al. 1992). This enzyme is a member of the short-chain alcohol dehydrogenase superfamily. The type $117 \beta$-HSD gene consists of 6 exons and 5 introns within a genomic DNA fragment of $3 \cdot 2 \mathrm{kbp}$ (Fig. 4). The type $117 \beta$-HSD gene was assigned by in situ hybridization to the $17 \mathrm{q} 11-\mathrm{q} 21$ region (Luu-The et al. 1989). The type $117 \beta-H S D$ enzyme is a cytosolic protein that exists in a homodimeric form that catalyses predominantly the interconversion of $\mathrm{E}_{1}$ to $\mathrm{E}_{2}$ using $\mathrm{NAD}(\mathrm{H})$ or $\mathrm{NADP}(\mathrm{H})$ as cofactor (Dumont et al. 1992, Lin et al. 1992). 
Type I 17B-HSD

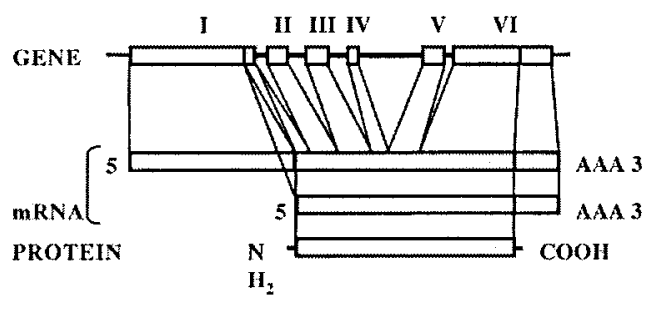

$3.2 \mathrm{~kb}$

$2.2 \mathrm{~kb}$

$1.3 \mathrm{~kb}$

327 a.a.

Type II 17B-HSD

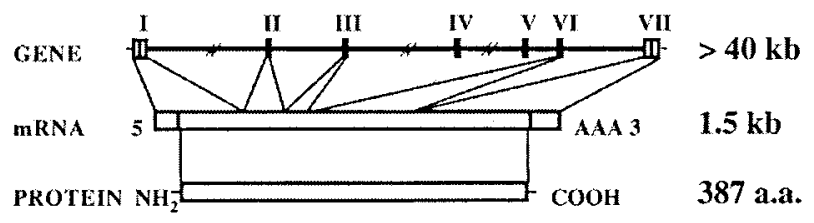

Type III 17i-HSD

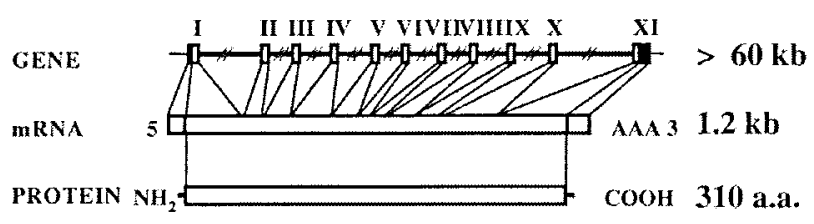

Type IV 17B-HSD

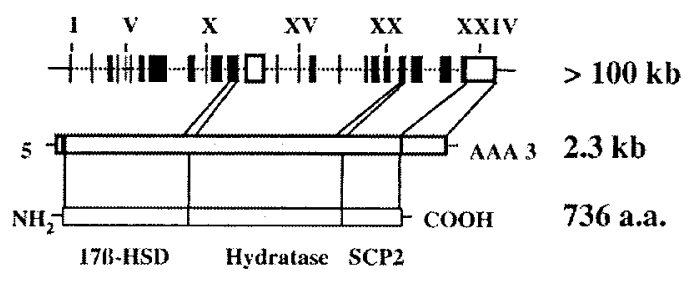

Type V 17ß-HSD

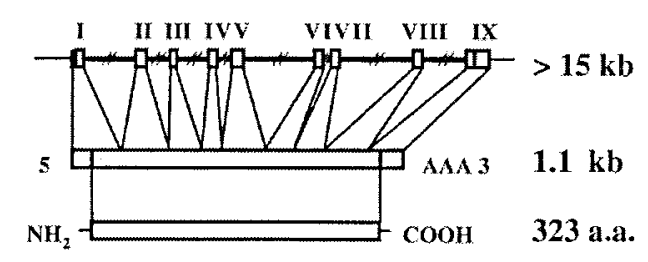

Type VII 17ß-HSD

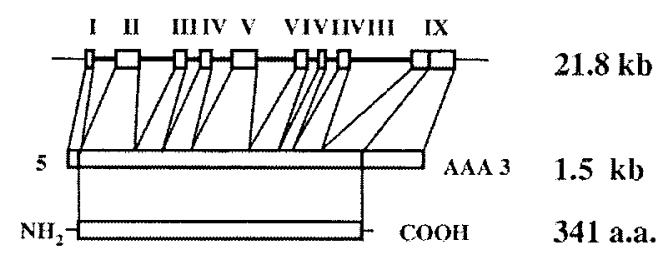

FIGURE 4. Structure of human types 1, 2, 3, 4, 5 and 7 17 $\beta$-HSD genes, mRNAs and corresponding proteins. a.a., amino acids.

In order to perform the structure-function analysis of type $117 \beta-\mathrm{HSD}$, the protein was rapidly purified, thus yielding a highly active preparation, and over-expressed in baculovirus and crystallized (Lin et al. 1992, Zhu et al.1993, Breton et al.1994). This work has led to the elucidation of its three-dimensional structure (Ghosh et al. 1995), thus achieving the first X-ray structure determination of a mammalian steroidogenic enzyme. The structure of type $117 \beta$-HSD from human placenta was determined at $2 \cdot 2 \AA$ resolution by a combination of isomorphous replacement (with a single mercury derivative) and molecular replacement techniques. The core of the structure is the seven-stranded parallel $\beta$-sheet ( $\beta$ A to $\beta G$ ), surrounded by six parallel $\alpha$-helices $(\alpha \mathrm{B}$ to $\alpha \mathrm{G})$, three on each side of the $\beta$-sheet (Fig. 5). The first structure of type 1 of $17 \beta$-HSD has shown that the enzyme has a folding characteristic of short-chain dehydrogenase with Tyr155, Lys159 and Ser142 constituting the catalytic triangle of the enzyme.

After determination of the first 3-D structure of the enzyme, we have studied in detail the substrate specificity of the enzyme. In its complex with the most potent estrogen, namely estradiol, it has been observed that the specificity of the enzyme was determined, in part, by four hydrogen interactions which determine the substrate orientation, as well as by important hydrophobic interactions between the steroid and the hydrophobic surface in the binding site, thus contributing the most thermodynamic force for binding. The binding site is a narrow hydrophobic tunnel showing a high degree of complementarity to the substrate (Azzi et al. 1996, Lin et al. 1999).

To understand further the discrimination between various steroids by type $117 \beta$-HSD, we crystallized and determined the structures of type 1 $17 \beta$-HSD complexes with DHEA and DHT, providing the first pictures of DHEA and DHT bound to a protein. Comparison of these structures with the enzyme-estradiol complex shows that relatively small changes in the shape of the steroid molecule can markedly affect the binding affinity and specificity. In fact, the $K_{\mathrm{m}}$ of estrone is more than 1000-fold lower than that of DHEA while the $K_{\mathrm{m}}$ of estradiol is about 10 times lower than that of DHT. The structures suggest that Leu149 is the 


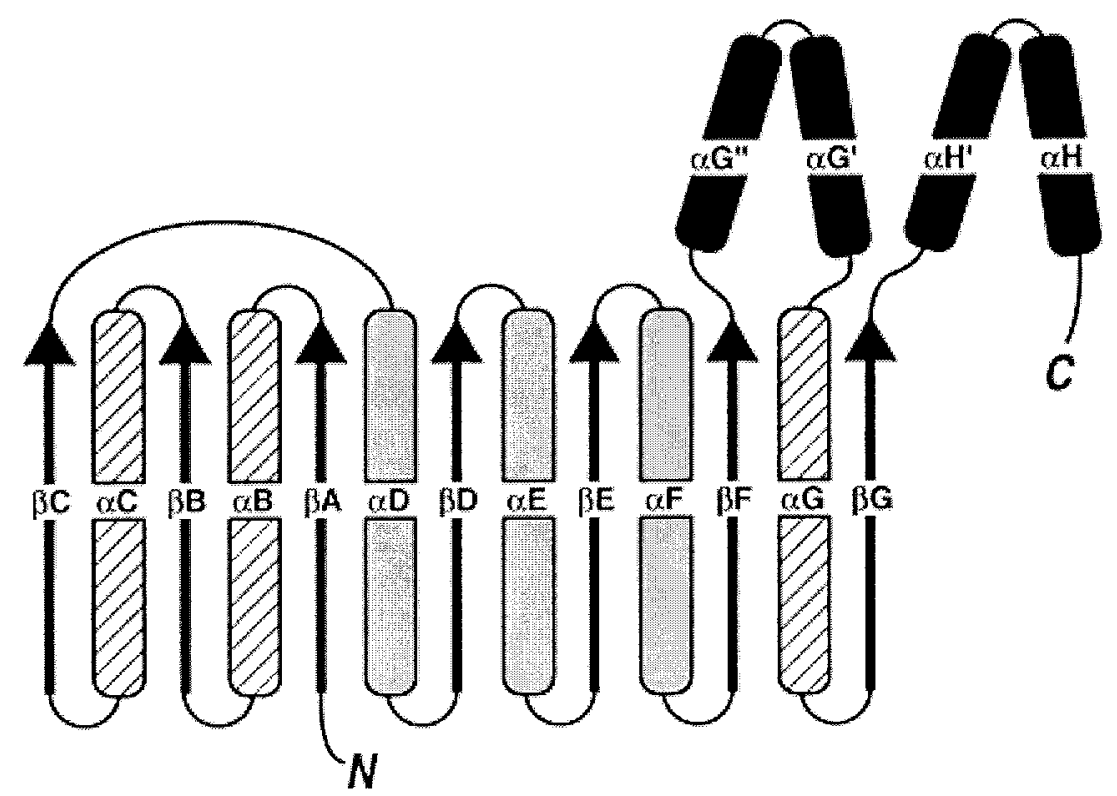

FIGURE 5. Secondary structure pattern in $17 \beta$-HSD with $\beta$-strands represented by solid arrows and $\alpha$-helix by tubes. The light gray $\alpha$-helices are on one side of the $\beta$-sheet (towards the viewer) while the hatched $\alpha$-helices are on the opposite side of the $\beta$-sheet (away from the viewer). Reproduced from Labrie et al. (1998) with permission.

primary contributor to the discrimination of C18/C19 steroids by type $117 \beta-H S D$. The critical role of Leu149 has been confirmed by site-directed mutagenesis. The Leu149Val variant showed a significantly decreased $K_{\mathrm{m}}$ for $\mathrm{C} 19$ steroids while losing discrimination between estrogens and androgens. The electron density of DHEA also revealed a distortion of its 17 -ketone group towards a $\beta$-oriented form (Han et al. 2000).

To elucidate the structure-function relationships more completely and to facilitate the design of inhibitors for this critical steroidogenic enzyme, we have studied the dynamics of the estradiol binding process. This study was carried out using MonteCarlo minimization with the crystallographic data as starting point. The results show that the movement of the steroid along the binding tunnel is accompanied by essential conformation rearrangements of the enzyme side chains, noticeable rotation of estradiol along its longitudinal axis, and some conformational changes of the steroid (Zhorov \& Lin 2000).

\section{Type 2 17ß-HSD}

The structure of a second type of $17 \beta-H S D$ cDNA was then reported (Wu et al. 1993). This cDNA encodes a predicted protein of 387 amino acids with a molecular mass of 42782 (Fig. 4); it is most likely associated with the membranes of the endoplasmic reticulum. This enzyme catalyzes the conversion of $\mathrm{E}_{2}$ into estrone, testosterone into 4-dione and 5-diol into DHEA. This enzyme, chronologically designated type $217 \beta-\mathrm{HSD}$, is also a member of the short-chain alcohol dehydrogenase super-family but it shares only about $20 \%$ sequence identity with the cytoplasmic enzyme encoded by the type $117 \beta$-HSD gene (Luu-The et al. 1989). This enzyme uses $\mathrm{NAD}(\mathrm{H})$ as a cofactor (Wu et al. 1993). It is less specific than type $117 \beta$-HSD since it uses both estrogens and androgens as substrates.

\section{Type 3 17ß-HSD}

A third type of human $17 \beta$-HSD cDNA encoding a predicted protein of 310 amino acids with a molecular mass of 34513 was then characterized (Geissler et al. 1994) (Fig. 4). Type 3 17ß-HSD, a microsomal isozyme, uses $\mathrm{NADP}(\mathrm{H})$ as a cofactor, and is expressed predominantly in the testes, with an equilibrium of the reaction favoring testosterone production from 4-dione. This enzyme, which shares $23 \%$ sequence identity with the two other $17 \beta$-HSD enzymes, is the site of the mutations responsible for male pseudohermaphroditism from 
$17 \beta$-HSD deficiency (Geissler et al. 1994). The type $317 \beta$-HSD mRNA species was detected only in the testes out of the 16 tissues tested by Northern blot analysis (Geissler et al. 1994).

\section{Type 4 17ß-HSD}

Human type $417 \beta-H S D$ is a 736 amino acid protein of $M_{\mathrm{r}} 80 \mathrm{kDa}$ (Fig. 4) which shares $84 \%$ identity with the corresponding porcine enzyme and transforms $\mathrm{E}_{2}$ into $\mathrm{E}_{1}$ and 5-diol into DHEA (Leenders et al. 1994, Adamski et al. 1995). The human type $417 \beta$-HSD mRNA is expressed in virtually all human tissues examined by Northern blot, including the liver, heart, prostate, testis, lung, skeletal muscle, kidney, pancreas, thymus, ovary, intestine, placenta, and several human breast cancer cell lines. Thus, this enzyme is likely to play an important role in the inactivation of estrogens in a large series of peripheral tissues.

\section{Type 5 17ß-HSD}

While type 3 17 $\beta$-HSD synthesizes testosterone from 4-dione in the Leydig cells of the testicles, thus providing approximately $50 \%$ of the androgens acting in the prostate and other androgen-sensitive tissues, the same enzymatic reaction is catalyzed in peripheral tissues by another enzyme, namely type 5 $17 \beta$-HSD. This enzyme belongs to the aldo-keto reductase family. In fact, type $517 \beta$-HSD is highly homologous with types 1 and $33 \alpha$-HSDs as well as 20a-HSD (Dufort et al. 1999).

To assess the importance of type $517 \beta$-HSD in peripheral tissues, especially in the prostate, we used an RNase protection assay to detect specifically the level of type $517 \beta$-HSD mRNA expression in the liver, adrenal, and prostate as well as in the prostatic carcinoma cell lines DU-145 and LNCaP and in the osteosarcoma cells MG-63. Type 5 $17 \beta$-HSD mRNA was found in all the tissues mentioned above. However, the level of mRNA expression in the normal prostate and adrenal was lower than that in the liver, prostatic cancer, and osteocarcinoma cells.

We will now use the human prostate as an example of the potential role of type $517 \beta$-HSD as a local source of androgens. As mentioned earlier, approximately $50 \%$ of androgens in the human prostate are synthesized locally from the inactive adrenal precursors DHEA and DHEA-S of adrenal origin. In order to obtain more precise information about the localization and potential role of type 5 $17 \beta$-HSD in this tissue, we have used two complementary approaches, namely in situ hybridization and immunocytochemistry, in order to properly identify the human prostatic cells which contain the type $517 \beta$-HSD mRNA and the corresponding enzyme. Localization of $3 \beta-\mathrm{HSD}$ and of the androgen receptor (AR) was also investigated by immunostaining in the same tissue.

The stratified epithelium lining the tube-alveoli of the human prostate is divided into two layers, namely the basal layer made of low cuboidal cells located underneath a layer of columnar secretory cells (luminal cells) (Fig. 6). In the glandular epithelium, the basal cells highly express the type 5 $17 \beta$-HSD enzyme while luminal cells show a much lower and variable level of expression (Fig. 6A). Similar results are observed when the cellular distribution of $3 \beta-\mathrm{HSD}$ is investigated (Fig. 6B). The in situ hybridization results obtained with a $\left[{ }^{3} \mathrm{H}\right] \mathrm{UTP}$-labeled type $517 \beta-\mathrm{HSD}$ riboprobe are in agreement with the immunostaining data obtained with a specific antibody to the enzyme (El-Alfy et al. 1999). The immunostaining results obtained from normal prostate tissue and benign prostatic hyperplasia (BPH) were found to be similar. Androgen receptor immunoreactivity, on the other hand, shows a different distribution since, in the prostatic epithelium, most of the nuclei of basal cells are negative while the majority of nuclei of the luminal cells show intense and positive staining (Fig. 6C).

In conclusion, human type $517 \beta-\mathrm{HSD}$, as well as $3 \beta$-HSD are highly expressed in the basal epithelial cells of the human prostate. AR, on the other hand, is highly expressed in the luminal cells. The present data suggest that DHEA is transformed in the basal cells of the glandular epithelium into 4-dione by $3 \beta$-HSD and then into testosterone by type 5 $17 \beta$-HSD, while DHT appears to be synthesized in both the basal and luminal cells by $5 \alpha$-reductase (El-Alfy et al. 1999) (Fig. 7).

It is generally believed that prostatic stem cells are located in the basal cell compartment (Bonkhoff $\&$ Remberger 1998). The presence of type 5 $17 \beta$-HSD, $3 \beta$-HSD and $5 \alpha$-reductase isoenzymes in the basal cells suggests that this cell type is actively involved in androgen production and cannot be considered as being only a precursor of the luminal secretory cells.

It is clear from the data obtained that the androgen receptor is localized exclusively in the nuclei of the luminal cells. This finding is in agreement with the observation that androgen blockade in men treated for prostate cancer leads to an atrophy and even, after long-term androgen blockade, disappearance of the luminal cells by apoptosis. The basal cells, on the other hand, are not affected by androgen deprivation.

Concerning the site of DHT synthesis, the presence of $5 \alpha$-reductase in the basal cells suggests 

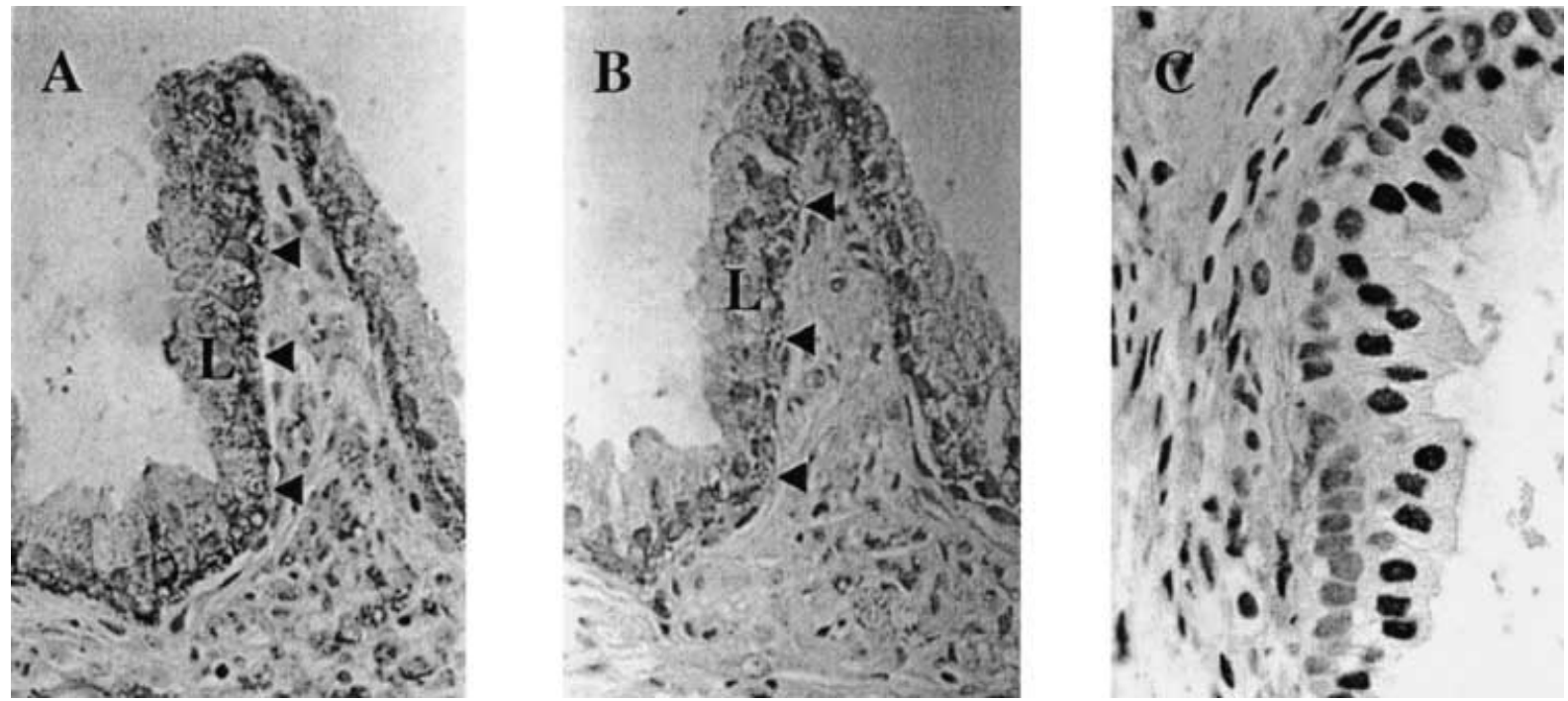

FIGURE 6. Paraffin sections of BPH tissue, immunostained with antibodies for (A) type 5 17 $\beta-H S D$, (B) $3 \beta$-HSD and $(\mathrm{C})$ AR $(\times 800)$. Consecutive sections were immunostained for type 5 17 $\beta$-HSD $(\mathrm{A})$ and $3 \beta$-HSD (B). Although the reaction for $3 \beta$-HSD is somewhat weaker than that obtained for type $517 \beta$-HSD, the distribution of the two enzymes in basal (arrowheads) and luminal cells (L) is similar. (C) AR immunoreactivity was found to be exclusively localized in the nuclei. In the epithelium, the reaction can be seen in the majority of the luminal cells (L) nuclei, but not in the nuclei of most basal cells (El-Alfy et al. 1999).

that the DHT made in basal cells is then transferred to luminal cells where interaction with the androgen receptor takes place. On the other hand, since type 5 $17 \beta$-HSD and $3 \beta$-HSD are both highly expressed in basal cells but not in the luminal cells while the androgen receptor is mainly present in the luminal cells which also contain $5 \alpha$-reductase, it is tempting to suggest that an undefined proportion of testosterone synthesized in the basal cells diffuses or is transported into the luminal cells where it is ultimately transformed into DHT by $5 \alpha$-reductase (Fig. 7). DHT made in the luminal cells by the action of $5 \alpha$-reductase exerts its action in the luminal cells themselves.

The involvement of two cell types in the biosynthesis of steroids has already been shown to occur in the ovary. In fact, in the ovary, C19 steroids (4-dione and testosterone) synthesized by theca interna cells are transferred to granulosa cells where they are aromatized into estrogens (McNatty et al. 1979). The present data strongly suggest the possibility of a similar two-cell mechanism of androgen formation in the human prostate: testosterone is first synthesized in the basal cells before diffusing into the luminal cells where transformation into DH'T occurs. DH'T is also made in basal cells. As mentioned above, the basal cells of the human prostate are themselves unresponsive to androgens.

\section{Type 6 17-HSD}

Using a rat prostate cDNA obtained by expression cloning, Biswas and Russell (1997) have isolated cDNA clones which metabolize $3 \alpha$-diol. Among the many clones obtained, one type termed type 6 $17 \beta-H S D$ catalyzes selectively the oxidation of $3 \alpha$-diol to androsterone. However, the transformation of other C19 steroids, namely DHT to androstanedione (A-dione) and testosterone to 4-dione also occurs but at an approximately 50to 100 -fold lower rate.

Type $617 \beta$-HSD shares $65 \%$ homology with rat type 1 retinol dehydrogenase (RoDH1) and thus belongs to the retinol dehydrogenase family. Retinol dehydrogenase is well recognized to catalyze the transformation of retinol to retinal (Chai et al. 1995). Many members of this family, such as rat RoDH1, human RoDH1 (Biswas \& Russell 1997) and 9-cis-RoDH (Huang et al. 1998), also show oxidative $3 \alpha$-HSD activity that transforms $3 \alpha$-diol to DHT and ADT to A-dione. Northen blot analysis shows high expression of type $617 \beta$-HSD in rat liver and prostate. However, because of the relatively high homology with other members of the retinol dehydrogenase family, the high signal observed could also be due to the presence of other RoDH members. The size of the message is approximately $2 \mathrm{~kb}$. 


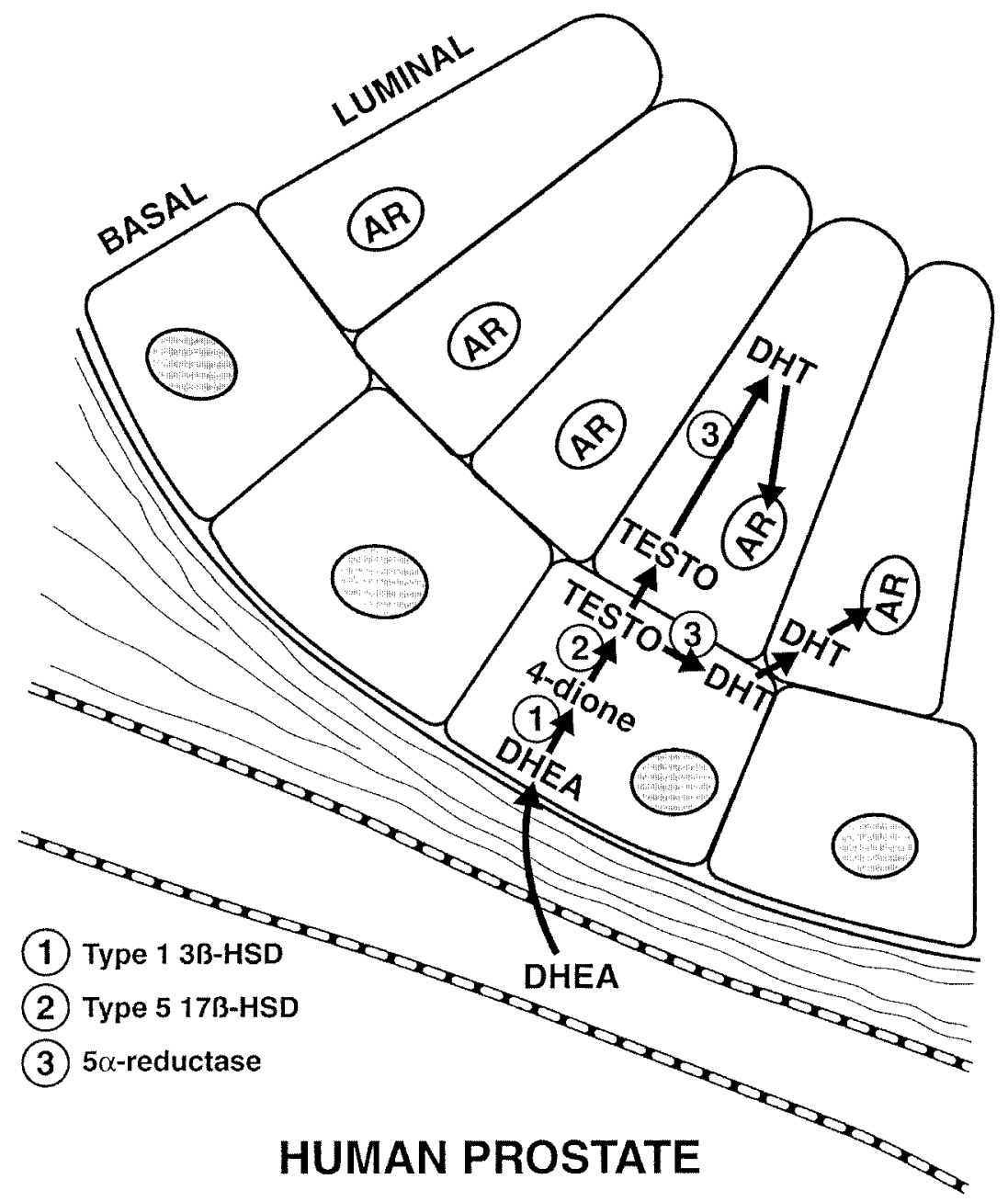

FIGURE 7. Schematic representation of the intracrine formation of androgens in the human prostate. In basal cells of the prostatic epithelium, the inactive precursor DHEA is transformed into androstenedione by $3 \beta-\mathrm{HSD}$ and then into the weak androgen, testosterone (TESTO), by type $517 \beta-\mathrm{HSD}$. An undefined proportion of testosterone is then transformed into the most potent androgen, DHT, by $5 \alpha$-reductase in basal cells. Another fraction of testosterone is transported into the luminal cells where $5 \alpha$-reductase transforms testosterone into DHT. The androgen receptor (AR), on the other hand, is exclusively expressed in the nuclei of the luminal cells which are the site of prostate cancer development. Basal cells do not contain significant amounts of $\mathrm{AR}$ and are apparently unresponsive to androgens.

The human counterpart has not yet been described. Using rat type $617 \beta-\mathrm{HSD} \mathrm{cDNA}$ as probe to screen human liver and prostate cDNA libraries, we have obtained many other members of the RoDH family. However, a human clone that possesses the characteristics of rat type $617 \beta-\mathrm{HSD}$ has not been found.

\section{Type 7 17 $\beta$-HSD}

Type $717 \beta$-HSD was first cloned in a rat corpus luteum cDNA library and was identified as prolactin receptor associated protein (PRAP) (Duan et al. 1996). Using expression cloning of a mouse mammary epithelial (HC11) cell cDNA library, a clone 
that shares $89 \%$ identity with rat PRAP, and catalyzes selectively the transformation of $\mathrm{E}_{1}$ to $\mathrm{E}_{2}$ has been isolated (Nokelainen et al. 1998). Following transfection into HEK-293 cells, Nokelainen et al. (1998) also found that rat PRAP catalyzes efficiently and selectively the transformation of $\mathrm{E}_{1}$ to $\mathrm{E}_{2}$ while the transformation of $\mathrm{C} 19$ steroids was much weaker.

Northern blot analysis shows mRNAs having multiple sizes, the strongest bands being seen at $4 \cdot 6$ and $4.3 \mathrm{~kb}$ in the mouse and rat respectively. The $1.8 \mathrm{~kb}$ band that corresponds to the cDNA length is much weaker. Such results suggest that other type 7 $17 \beta$-HSD-like proteins could exist. Both rat and mouse 4.3 and 4.6 bands are abundantly expressed in the corpus luteum during the second half of pregnancy. On the other hand, only weak expression is observed in the non-pregnant ovary. The mRNA has also been detected in the placenta, mammary gland and kidney. Using RT-PCR, mRNA has also been observed in the mouse brain, testis and small intestine.

A human type 7 17 $\beta$-HSD cDNA clone (Krazeisen et al. 1999) shows a length of $1.5 \mathrm{~kb}$ and encodes a protein of $37 \mathrm{kDa}$ or 341 amino acids. Using RT-PCR, this enzyme is detected in the ovary, breast, placenta, testis, prostate and liver. It shows 74 and $78 \%$ amino acid identity with the mouse and rat type $717 \beta$-HSDs respectively. Comparison with other $17 \beta-H S D$ s indicates that it shares less than $20 \%$ identity, a typical percentage for the other members of the $17 \beta$-HSD family. Only the human type $717 \beta$-HSD gene structure has been described (Krazeisen et al. 1999). This gene spans $21.8 \mathrm{~kb}$ and consists of nine exons and eight introns. The gene is assigned to human chromosome bands $10 \mathrm{p} 11 \cdot 2$. It is noteworthy that type 5 $17 \beta$-HSD is also mapped to human chromosome 10 (bands 10p15 $\rightarrow 14$ ).

\section{Type 8 17ß-HSD}

Type $817 \beta$-HSD is also known as the Ke6 gene product found in the human leucocyte antigen (HLA) region (Kikuti et al. 1997). This area is well known to contain genes encoding the human major histocompatibility complex (MHC). This complex is thought to be involved in polycystic kidney disease (PKD) since aberrant expression has been found in two different models of PKD mice (Aziz et al. 1993). Recently, Fomitcheva et al. (1998) have found that the overexpressed protein fused with GST catalyzes efficiently the transformation of $\mathrm{E}_{2}$ to $\mathrm{E}_{1}$. The transformation of testosterone to 4-dione is about $25 \%$ of that of $E_{2}$ into $E_{1}$. In a recent review, Peltoketo et al. (1999) suggest that this enzyme be named type $817 \beta-H S D$. In addition to the kidney, the Ke6a protein is abundant in the mouse liver and gonads, while the Ke6b form is more specifically expressed in the spleen. Interestingly, in the mouse ovary, type $817 \beta$-HSD which catalyzes the reaction opposite to that of types 1 and $717 \beta$-HSD is expressed in cumulus cells but not in granulosa or luteal cells where types 1 and 7 $17 \beta$-HSD are more abundantly expressed (Nokelainen et al. 2000).

Although the human Ke6 gene has been known for a few years (Kikuti et al. 1997), the cDNA clone and thus the expressed protein has not been isolated and its activity is unknown. The gene encodes a protein of 274 amino acids. Whether human Ke6 protein possesses $17 \beta-\mathrm{HSD}$ activity thus remains to be determined.

\section{UNIDIRECTIONAL ACTIVITY OF 17ß-HSDs}

It is important to indicate, at this stage, that in intact cells, the activity catalyzed by each type of $17 \beta$-HSD is almost exclusively unidirectional: for example, types $1,3,5$ and $717 \beta$-HSDs catalyze the reaction in a reductive way, while types 2 and 4 $17 \beta-H S D s$ catalyze the oxidative reaction. In estrogen-target tissues, such as in the placenta and breast, the presence of type $117 \beta$-HSD ensures a high level of estradiol formation. Similarly, in the testis, type $317 \beta$-HSD drives the conversion of 4 -dione to the testosterone needed for the development and growth of the internal male reproductive structures (epididymis, seminal vesicles, and vas deferens) as well as for the development, growth and function of the secondary sex organs.

The cell-specific expression of the different $17 \beta$-HSDs implies that measurements of $17 \beta$-HSD activity in an intact and even more in an homogenized tissue, is the sum of the activities of the reductive and oxidative activities of the different enzymes expressed at various levels in the different cell types which constitute that tissue. As an example, when we studied the cell-specific expression of type $517 \beta$-HSD in the human prostate, we used in situ hybridization in order to assess the level of mRNA encoding the enzyme and we used immunocytochemistry to estimate the localization of the enzyme not only in each cell but also in different compartments of the cells.

Not only is each type of $17 \beta-H S D$ specifically expressed in individual cell types but, as shown in the few studies already performed, 17 $\beta$-HSD expression is modulated specifically in each cell by precise mechanisms in order to control the concentration of each sex steroid according to local needs. 


\section{LOCAL CONTROL OF ESTROGEN AND ANDROGEN FORMATION AND INACTIVATION BY 17ß-HSD IN BREAST CANCER}

Sex steroids are well recognized to play a predominant role in the regulation of cell growth and differentiation of normal mammary gland as well as in hormone-sensitive breast carcinomas. Estrogens stimulate proliferation of hormonesensitive breast cancer cells (Poulin \& Labrie 1986, Davidson \& Lippman 1989, King 1991, Bernstein \& Ross 1993), while androgens exert an antiproliferative action in these cells (Poulin \& Labrie 1986, Poulin et al. 1988, 1989, Labrie et al. 1992a). There is a large body of evidence showing that in the human, the local intracrine formation of active estrogens and androgens from inactive steroids precursors DHEA and DHEA-S regulate growth and function of peripheral target tissues, including the breast (Adams 1985, Labrie 1991, Labrie et al. $1997 a, b$, Couillard et al. 1998). Thus, the various types of human steroidogenic enzymes, namely $17 \beta$-HSD, $3 \beta$-HSD, $5 \alpha$-reductase and the alternative promoter usage of the aromatase gene, because of their tissue- and cell-specific expression and substrate specificity, provide each cell with the necessary mechanisms to control the level of intracellular active estrogens and androgens (Labrie 1991, Martel et al. 1994, Simard et al. 1996, Labrie et al. 1997c, Simpson et al. 1997).

In fact, the concentration of the potent estrogen $\mathrm{E}_{2}$ is significantly higher in breast tumor than in normal breast tissue (Bonney et al. 1983, Van Landedgem et al. 1985, Vermeulen et al. 1986, Recchione et al. 1995), while the tumor $\mathrm{E}_{2}$ concentration is much higher compared with that of $\mathrm{E}_{1}$ (Van Landedgem et al. 1985, Vermeulen et al. 1986). Moreover, a higher level of conversion of $\mathrm{E}_{1}$ to $\mathrm{E}_{2}$ compared with the reverse reaction was measured by direct uptake of labeled $\mathrm{E}_{1}$ or $\mathrm{E}_{2}$ in breast cancer tissue in postmenopausal women (McNeil et al. 1986).

It is therefore quite possible that higher reductive $17 \beta$-HSD activity contributes to higher levels of $\mathrm{E}_{2}$ in tumors, thus resulting in a progression of tumor growth. The $17 \beta$-HSD activity can therefore exert a key role in regulating the tissue concentration of active estrogens through control of interconversion of $\mathrm{E}_{1}$ and $\mathrm{E}_{2}$ as well as that of DHEA and 5-diol, the latter being a weak estrogen (Poulin \& Labrie 1986). In fact, in many estrogen receptor-positive (ER+) human breast cancer cell lines (MCF-7, ZR-75-1, and $\mathrm{T}-47 \mathrm{D})$, the reductive pathway leading to the formation of $\mathrm{E}_{2}$ from $\mathrm{E}_{1}$ is predominant (Adams et al. 1988a, Pasqualini et al. 1989, Poutanen et al.
1990, Couture et al. 1993), whereas in hormoneindependent cell lines (MDA-MB-231 and MDAMB-346), the oxidative pathway responsible for the inactivation of $\mathrm{E}_{2}$ into $\mathrm{E}_{1}$ predominates (Pasqualini et al. 1989). Numerous studies have reported the presence of multiple $17 \beta$-HSDs in human breast cancer cells (Tait et al. 1989, MacIndoe 1990, Poutanen et al. 1990, 1992, Martel et al. 1992).

Endocrine, paracrine as well as intracrine influences on the proliferation of human breast cancer cells can play a role, thus supporting the suggestion that breast tumor growth is modulated by the hormonal environment (Adams et al. 1988b,c, Dickson \& Lippman 1996). The presence in breast tumors of considerable numbers of tumorassociated macrophages and tumor-infiltrating lymphocytes secreting a wide spectra of cytokines also suggests a key role for these factors in neoplastic cell activity (Kelly et al. 1988, Whitford et al. 1990). Moreover, it has been observed that Natural Killer cells isolated directly from ductal invasive breast tumors secrete important amounts of interferon- $\gamma$ and interleukin (IL)-4 (Tamm et al. 1989). In support of the potential role of cytokines in breast cancer cells, IL-1 $\alpha$, IL-4, IL-6 and IL-13 inhibit the proliferation of ZR-75-1, T-47D and/or MCF-7 human breast cancer cells (Tamm et al. 1989, 1991, Toi et al. 1992, Blais et al. 1994, 1995, 1996, Serve et al. 1996, Douglas et al. 1997). Furthermore, it has already been reported that some cytokines can regulate the expression of several enzymes involved in sex steroid formation and inactivation in breast cells. For example, IL-6 regulates the expression of $17 \beta-H S D$ (Adams et al. 1991, Reed \& Purohit 1997, Turgeon et al. 1998), estrone sulfatase (Purohit et al. 1996) and P450 aromatase (Zhao et al. 1995) whereas IL-4 regulates $17 \beta$-HSD activity.

We first investigated the effect of exposure to IL- 4 and IL- 6 on reductive and oxidative $17 \beta-H S D$ activities in both intact ZR-75-1 and T-47D human breast cancer cells. In ZR-75-1 cells, a 6-day exposure to IL-4 and IL-6 decreased $\mathrm{E}_{2}$-induced cell proliferation, the half maximal inhibitory effect being exerted at $88 \mathrm{pM}$ and $26 \mathrm{pM}$ respectively. In parallel, incubation with IL-4 and IL-6 increased oxidative $17 \beta$-HSD activity by $4 \cdot 4$ - and $1 \cdot 9$-fold respectively, this potent activity being observed at $\mathrm{EC}_{50}$ values of $22 \cdot 8$ and $11 \cdot 3 \mathrm{pM}$ respectively (Fig. 8). ('Turgeon et al. 1998). Simultaneously, reductive $17 \beta$-HSD activity leading to $\mathrm{E}_{2}$ formation was decreased by 70 and $40 \%$ by IL-4 and IL-6 respectively. Moreover, IL-4 and IL-6 exerted the same regulatory effects on $17 \beta$-HSD activities when testosterone and 4-dione were used as substrates, 


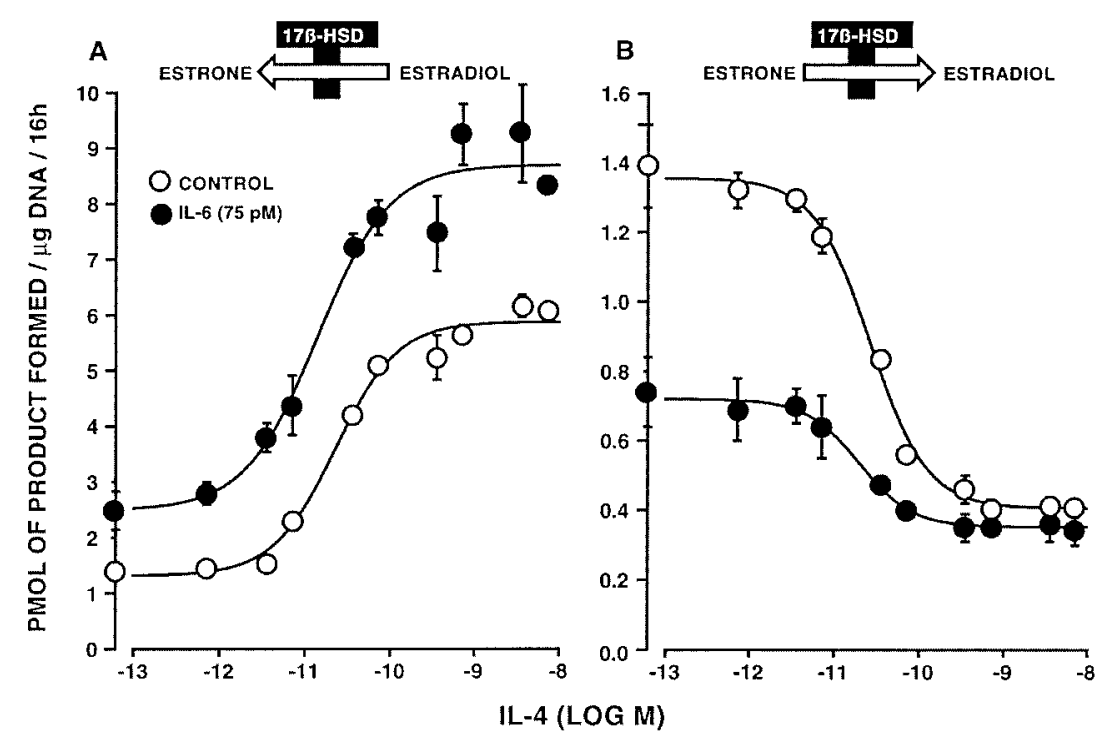

FIGURE 8. Effect of increasing concentrations of IL-4 in the presence or absence of IL-6 on the oxidative (A) and reductive (B) $17 \beta-\mathrm{HSD}$ activities in ZR-75-1 human breast cancer cells. Three days after plating, cells were incubated for 10 days with the indicated concentrations of IL-4 in the presence or absence of 75 pM IL-6, with changes of media every 2 days, prior to a $16-\mathrm{h}$ incubation with $10 \mathrm{nM}\left[{ }^{3} \mathrm{H}\right] \mathrm{E}_{2}(\mathrm{~A})$ or $\left[{ }^{3} \mathrm{H}\right] \mathrm{E}_{1}(\mathrm{~B})$. Data are expressed as means \pm s.E.M. $(n=3)$ (Turgeon et al. 1998).

thus strongly suggesting the expression of the type 2 $17 \beta-H S D$ in $Z R-75-1$ cells. In contrast, in T-47D cells, IL-4 increased the formation of $\mathrm{E}_{2}$, whereas IL-6 exerted no effect on this parameter. It was found, however, that T-47D cells failed to convert testosterone efficiently into 4-dione, thus suggesting that there is little or no expression of type 2 $17 \beta$-HSD in this cell line. The present findings demonstrate that the potent regulatory effects of IL-4 and IL-6 on 17ß-HSD activities depend on the cell-specific gene expression of various types of $17 \beta$-HSD enzymes. We have also studied the effect of cytokines on the regulation of the $3 \beta-\mathrm{HSD}$ expression in both ZR-75-1 and T-47D human breast cancer cells. However, exposure to IL-4 caused a rapid and potent induction of $3 \beta$-HSD activity, whereas IL-6 failed to induce $3 \beta$-HSD expression. Such data thus demonstrate that cytokines may play a crucial role in sex steroid biosynthesis from inactive adrenal precursors in human breast cancer cells.

\section{IMPLICATION OF 17ß-HSD IN PHYSIOLOGY AND DISEASE}

In the human, the continuous formation of sex steroids from DHEA in peripheral tissues is likely to play a major role in the maintenance of adequate functioning of most human tissues. Knowledge of this important role of intracrinology should be helpful in the design of better adapted therapies for the prevention and treatment of sex steroidsensitive cancers, especially prostate and breast cancer which are the two most common cancers in men and women and the second greatest cause of cancer deaths. Intracrinology should also play an important role in the understanding, prevention and treatment of the important changes associated with menopause, namely osteoporosis and cardiovascular disease. Being at the final step in the formation of all active estrogens and androgens, it is clear that $17 \beta$-HSDs have a unique role to play in sex steroid physiology and hormone-sensitive disease.

\section{REFERENCES}

Adams EF, Coldham NG \& James VHT 1988a Steroidal regulation of oestradiol-17 $\beta$-dehydrogenase activity of the human breast cancer cell line MCF-7. Fournal of Endocrinology 118 149-154.

Adams EF, Newton CJ, Braunsberg H, Shaikh N, Ghilchik M \& James VHT $1988 b$ Effects of human breast fibroblasts on growth and $17 \beta$-estradiol dehydrogenase activity in MCF-7 cells in culture. Breast Cancer Research and Treatment 11 165-172. 
Adams EF, Newton CJ, Tait GH, Braunsberg H, Reed MJ \& James VHT 1988c Paracrine influence of human breast stromal fibroblasts on breast epithelial cells: secretion of a polypeptide which stimulates reductive $17 \beta$-estradiol dehydrogenase activity. International Fournal of Cancer $\mathbf{4 2}$ 119-122.

Adams EF, Rafferty B \& White MC 1991 Interleukin 6 is secreted by breast fibroblasts and stimulates $17 \beta$-oestradiol oxidoreductase activity of MCF-7 cells; possible paracrine regulation of breast 17 -oestradiol levels. International Fournal of Cancer 49 118-121.

Adams JB 1985 Control of secretion and the function of C19- $\Delta 5$ steroids of the human adrenal gland. Molecular and Cellular Endocrinology 41 1-17.

Adamski J, Normand T, Leenders F, Monté D, Begue A, Stehelin D, Jungblut PW \& de Launoit Y 1995 Molecular cloning of a novel widely expressed human $80 \mathrm{kDa}$ $17 \beta$-hydroxysteroid dehydrogenase IV. Biochemical fournal $311437-443$

Aziz N, Maxwell MM, St Jacques B \& Brenner BM 1993 Downregulation of Ke6, a novel gene encoded within the major histocompatibility complex, in murine polycystic kidney disease (published erratum appears in Molecular and Cellular Biology 1993 Oct 13(10) 6614). Molecular and Cellular Biology 13 1847-1853.

Azzi A, Rehse P, Zhu DW, Campbell RL, Labrie F \& Lin SX 1996 Crystal structure of human estrogenic $17 \beta-$ hydroxysteroid dehydrogenase complexed with $17 \beta$-estradiol. Nature Structural Biology 3 665-668.

Bélanger B, Bélanger A, Labrie F, Dupont A, Cusan L \& Monfette G 1989 Comparison of residual C-19 steroids in plasma and prostatic tissue of human, rat and guinea pig after castration: unique importance of extra-testicular androgens in men. Fournal of Steroid Biochemistry 32 695-698.

Bennett CL, Tosteson TD, Schmitt B, Weinberg PD, Ernstoff MS \& Ross SD 1999 Maximum androgen-blockade with medical or surgical castration in advanced prostate cancer: a meta-analysis of nine published randomized controlled trials and 4128 patients using Flutamide. Prostate Cancer Prostatic Disease 2 4-8.

Bernstein L \& Ross RK 1993 Endogenous hormones and breast cancer risk. Epidemiology Reviews 15 48-65.

Biswas MG \& Russell DW 1997 Expression cloning and characterization of oxidative $17 \beta$ - and $3 \alpha$-hydroxysteroid dehydrogenase from rat and human prostate. Fournal of Biological Chemistry 272 15959-15966.

Blais Y, Sugimoto K, Carrière MC, Haagensen DE, Labrie F \& Simard J 1994 Potent stimulatory effect of interleukin-1 $\alpha$ on apolipoprotein D and gross cystic disease fluid protein-15 expression in human breast-cancer cells. International Fournal of Cancer 59 400-407.

Blais $\mathrm{Y}$, Sugimoto $\mathrm{S}$, Carrière MC, Haagensen DE, Labrie F \& Simard J 1995 Interleukin-6 inhibits the potent stimulatory action of androgens, glucocorticoids and interleukin- $1 \alpha$ on apolipoprotein D and GCDFP-15 expression in human breast cancer cells. International Fournal of Cancer 6 732-737.

Blais Y, Gingras S, Haagensen DE, Labrie F \& Simard J 1996 Interleukin-4 and interleukin-13 inhibit estrogen-induced breast cancer cell proliferation and stimulate GCDFP-15 expression in human breast cancer cells. Molecular and Cellular Endocrinology 121 11-18.

Bonkhoff H \& Remberger K 1998 Morphogenesis of benign prostatic hyperplasia and prostatic carcinoma. Pathologe 19 $12-20$.

Bonney RC, Reed MJ, Davidson K, Beranek PA \& James VH 1983 The relationship between $17 \beta$-hydroxysteroid dehydrogenase activity and oestrogen concentrations in human breast tumours and in normal breast tissue. Clinical Endocrinology $19727-739$.

Breton R, Yang F, Jin JZ, Li B, Labrie F \& Lin SX 1994 Human 17ß-hydroxysteroid dehydrogenase: overproduction using a baculovirus expression system and characterization. Fournal of Steroid Biochemistry and Molecular Biology $\mathbf{5 0}$ 275-282.

Buzdar AU, Smith R, Vogel C, Bonomi P, Keller AM, Favis G, Mulagha M \& Cooper J 1996 Fadrozole HCL (CGS16949A) versus megestrol acetate treatment of postmenopausal patients with metastatic breast carcinoma: results of 2 randomized double-blind controlled multiinstitutional trials. Cancer 77 2503-2513.

Caubet JF, Tosteson TD, Dong EW, Naylon EM, Whiting GW, Ernstoff MS \& Ross SD 1997 Maximum androgen blockade in advanced prostate cancer: a meta-analysis of published randomized controlled trials using nonsteroidal antiandrogens. Urology 49 71-78.

Chai X, Boerman MH, Zhai Y \& Napoli JL 1995 Cloning of a cDNA for liver microsomal retinol dehydrogenase. A tissuespecific, short-chain alcohol dehydrogenase. Fournal of Biological Chemistry 270 3900-3904.

Couillard S, Gutman M, Labrie C \& Labrie F 1998 Effect of combined treatment using radiotherapy and the antiestrogen EM-800 on ZR-75-1 human mammary carcinoma growth in nude mice. Proceedings of the 89th American Association for Cancer Research p 382. New Orleans, LA, March 28-April 1 1998.

Couture P, Thériault C, Simard J \& Labrie F 1993 Androgen receptor-mediated stimulation of $17 \beta$-hydroxysteroid dehydrogenase activity by dihydrotestosterone and medroxyprogesterone acetate in ZR-75-1 human breast cancer cells. Endocrinology 132 179-185.

Crawford ED, Eisenberger MA, McLeod DG, Spaulding JT, Benson R, Dorr FA, Blumenstein DA, Davis MA \& Goodman PJ 1989 A controlled trial of leuprolide with and without flutamide in prostatic carcinoma. New England Fournal of Medicine 321 419-424.

Cummings SR, Eckert S, Krueger KA, Grady D, Powles TJ, Cauley JA, Norton L, NickelsenT, Bjarnason NH, Morrow M, Lippman ME, Black D, Glusman JE, Costa A \& Jordan VC 1999 The effect of raloxifene on risk of breast cancer in postmenopausal women: results from the MORE randomized trial. Multiple Outcomes of Raloxifene Evaluation (see comments). FAMA 281 2189-2197.

Cutler Jr GB, Glenn M, Bush M, Hodgen GD, Graham CE \& Loiaux DL 1978 Adrenarche: a survey of rodents, domestic animals and primates. Endocrinology 103 2112-2118.

Davidson NE \& Lippman ME 1989 The role of estrogens in growth regulation of breast cancer. Critical Reviews in Oncology 1 89-111.

Dickson RB \& Lippman ME 1996 Autocrine and paracrine growth factors in the normal and neoplastic breast. In Diseases of the Breast, pp 272-292. Eds JR Harris, ME Lippman, M Morrow \& S Hellmn. Philadelphia: Lippincott-Raven

Douglas AM, Goss GA, Sutherland RL, Hilton DJ, Bernst MC, Nicola NA \& Begley CG 1997 Expression and function of the cytokine receptor superfamily on breast cancer. Oncogene 14 661-669.

Duan WR, Linzer DIH \& Gibori G 1996 Cloning and characterization of an ovarian-specific protein that associates with the short form of the prolactin receptor. Fournal of Biological Chemistry 271 15602-15607.

Dufort I, Rheault P, Huang XF, Soucy P \& Luu-The V 1999 Characteristics of a highly labile human type $517 \beta$ hydroxysteroid dehydrogenase. Endocrinology 140 1-7. 
Dumont M, Luu-The V, de Launoit Y \& Labrie F 1992 Expression of human 17ß-hydroxysteroid dehydrogenase in mammalian cells. Fournal of Steroid Biochemistry and Molecular Biology 41 605-608.

El-Alfy M, Luu-The V, Huang XF, Berger L, Labrie F \& Pelletier G 1999 Localization of type 5 17ß-hydroxysteroid dehydrogenase, $3 \beta$-hydroxysteroid dehydrogenase and androgen receptor in the human prostate by in situ hybridization and immunocytochemistry. Endocrinology 140 1481-1491.

Fomitcheva J, Baker ME, Anderson E, Lee GY \& Aziz N 1998 Characterization of Ke6, a new 17 beta-hydroxysteroid dehydrogenase, and its expression in gonadal tissues. Fournal of Biological Chemistry 273 22664-22671.

Geissler WM, Davis DL, Wu L, Bradshaw KD, Patel S, Mendoça BB, Elliston KO, Wilson JD, Russel DW \& Andersson S 1994 Male pseudohermaphroditism caused by mutations of testicular 17 $\beta$-hydroxysteroid dehydrogenase 3 . Nature Genetics 7 34-39.

Ghosh D, Pletnev VZ, Zhu DW, Wawrzak Z, Duax WL, Pangborn W, Labrie F \& Lin SX 1995 Structure of human estrogenic $17 \beta$-hydroxysteroid dehydrogenase at $2 \cdot 20 \AA$ resolution. Structure 3 503-513.

Han Q, Campbell R-L, Gangloff A, Huang YW \& Lin S-X 2000 DHEA and DHT recognition by human estrogenic $17 \beta$-hydrosteroid dehydrogenase: C18/C19 steroid discrimination and enzyme-induced strain. Fournal of Biological Chemistry 275 1105-1111.

Hobkirk R 1993 Steroid sulfation: current concepts. Trends in Endocrinology and Metabolism 4 69-74.

Huang XF, Labrie F \& Luu-The V 1998 Recombinant human 11-cis retinol dehydrogenase expresses high 3-hydroxysteroid 9-oxydative activity. Abstracts of the Xth International Congress on Hormonal Steroids, Quebec, p 209, abstract no 192A.

Kelly PM, Davison RS, Bliss E \& McGee JO 1988 Macrophages in human breast disease: a quantitative immunohistochemical study. British Fournal of Cancer $\mathbf{5 7}$ 174-177.

Kikuti YY, Tamiya G, Ando A, Chen L, Kimura M, Ferreira E, Tsuji K, Trowsdale J \& Inoko H 1997 Physical mapping $220 \mathrm{~kb}$ centromeric of the human MHC and DNA sequence analysis of the $43-\mathrm{kb}$ segment including the RING1, HKE6, and HKE4 genes. Genomics 42 422-435.

King RGB 1991 A discussion of the roles of estrogen and progestin in human mammary carcinogenesis. Fournal of Steroid Biochemistry and Molecular Biology 39 811-818.

Krazeisen A, Breitling R, Imai K, Fritz S, Moller G \& Adamski J 1999 Determination of cDNA, gene structure and chromosomal localization of the novel human 17 betahydroxysteroid dehydrogenase type 7 (1). FEBS Letters 460 373-379.

Labrie C, Bélanger A \& Labrie F 1988 Androgenic activity of dehydroepiandrosterone and androstenedione in the rat ventral prostate. Endocrinology 123 1412-1417.

Labrie F 1991 Intracrinology. Molecular and Cellular Endocrinology 78 C113-C118.

Labrie F 1993 Intracrinology: its impact on prostate cancer. Current Opinion in Urology 3 381-387.

Labrie F 2000 Screening and hormonal therapy of localized prostate cancer show major benefits on survival. Cancer Fournal 6(Suppl 2) S182-S187.

Labrie F, Dupont A, Bélanger A, Cusan L, Lacourcière Y, Monfette G, Laberge JG, Emond J, Fazekas AT, Raynaud JP \& Husson JM 1982 New hormonal therapy in prostatic carcinoma: combined treatment with an LHRH agonist and an antiandrogen. Clinical and Investigative Medicine $\mathbf{5}$ $267-275$.
Labrie F, Dupont A \& Bélanger A $1985 a$ Complete androgen blockade for the treatment of prostate cancer. In Important Advances in Oncology, pp 193-217. Eds VT de Vita, S Hellman \& SA Rosenberg. Philadelphia: JB Lippincott.

Labrie F, Dupont A, Bélanger A, Giguère M, Lacourcière Y, Emond J, Monfette G \& Bergeron N $1985 b$ Combination therapy with flutamide and castration (LHRH agonist or orchiectomy) in advanced prostate cancer: a marked improvement in response and survival. Fournal of Steroid Biochemistry 23 833-841.

Labrie F, Simard J, de Launoit Y, Poulin R, Thériault C, Dumont M, Dauvois S, Martel C \& Li S $1992 a$ Androgens and breast cancer. Cancer Detection and Prevention 16 31-38.

Labrie F, Simard J, Luu-The V, Bélanger A \& Pelletier G $1992 b$ Structure, function and tissue-specific gene expression of $3 \beta$-hydroxysteroid dehydrogenase/5-ene-4-ene isomerase enzymes in classical and peripheral intracrine steroidogenic tissues. Fournal of Steroid Biochemistry and Molecular Biology 43 805-826.

Labrie F, Dupont A, Simard J, Luu-The V \& Bélanger A 1993 Intracrinology: the basis for the rational design of endocrine therapy at all stages of prostate cancer. European Urology 24 (Suppl 2) 94-105.

Labrie F, Bélanger A, Cusan L, Simard J, Luu-The V, Labrie C, Gomez JL, Diamond P \& Candas B $1996 a$ History of LHRH agonists and combination therapy in prostate cancer. Endocrine-Related Cancer 3 243-278.

Labrie F, Simard J, Luu-The V, Bélanger A, Pelletier G, Morel Y, Mebarki F, Sanchez R, Durocher F, Turgeon C, Labrie Y, Rhéaume E, Labrie C \& Lachance Y $1996 b$ The $3 \beta$-hydroxysteroid dehydrogenase/isomerase gene family: lessons from type II $3 \beta$-HSD congenital deficiency, In Signal Transduction in Testicular Cells. Ernst Schering Research Foundation Workshop, pp 185-218. Eds V Hansson, FO Levy \& K Taskén. Berlin, Heidelberg/New York: Springer-Verlag.

Labrie F, Bélanger A, Cusan L \& Candas B $1997 a$ Physiological changes in DHEA are not reflected by the serum levels of active androgens and estrogens but of their metabolites: intracrinology. Fournal of Clinical Endocrinology and Metabolism 82 2403-2409.

Labrie F, Diamond P, Cusan L, Gomez JL \& Bélanger A $1997 b$ Effect of 12-month DHEA replacement therapy on bone, vaginum, and endometrium in postmenopausal women. Fournal of Clinical Endocrinology and Metabolism 82 3498-3505.

Labrie F, Luu-The V, Lin SX, Labrie C, Simard J, Breton R \& Bélanger A $1997 c$ The key role of $17 \beta$-HSDs in sex steroid biology. Steroids 62 148-158.

Labrie F, Bélanger A, Luu-The V, Labrie C, Simard J, Cusan L, Gomez JL \& Candas B 1998 DHEA and the intracrine formation of androgens and estrogens in peripheral target tissues: its role during aging. Steroids $\mathbf{6 3} 322-328$.

Labrie F, Cusan L, Gomez JL, Belanger A \& Candas B 1999 Long-term combined androgen blockade alone for localized prostate cancer. Molecular Urology 3 217-225.

Leenders F, Adamski J, Husen B, Thole HH \& Jungblut PW 1994 Molecular cloning and amino acid sequence of the porcine 17 beta-estradiol dehydrogenase. European fournal of Biochemistry 222 221-227.

Lin SX, Yang F, Jin JZ, Breton R, Zhu DW, Luu-The V \& Labrie F 1992 Subunit identity of the dimeric $17 \beta$-hydroxysteroid dehydrogenase from human placenta. Fournal of Biological Chemistry 267 16182-16187.

Lin SX, Han Q, Azzi A, Zhu DW, Gangloff A \& Campbell RL 1999 3D-structure of human estrogenic 17 $\beta$-HSD1: binding with various steroids. Fournal of Steroid Biochemistry and Molecular Biology 69 425-429. 
Luu-The V, Labrie C, Zhao HF, Couët J, Lachance Y, Simard J, Leblanc G, Côté J, Bérubé D, Gagné R \& Labrie F 1989 Characterization of cDNAs for human estradiol $17 \beta$-dehydrogenase and assignment of the gene to chromosome 17: evidence of two mRNA species with distinct $5^{\prime}$ termini in human placenta. Molecular Endocrinology $\mathbf{3}$ 1301-1309.

Luu-The V, Labrie C, Simard J, Lachance Y, Zhao HF, Couët J, Leblanc G \& Labrie F 1990 Structure of two in tandem human 17 $\beta$-hydroxysteroid dehydrogenase genes. Molecular Endocrinology 4 268-275.

MacIndoe JH, Hinkhouse M \& Woods G 1990 Dehydroepiandrosterone and estrone 17-ketosteroid reductases in MCF-7 human breast cancer cells. Breast Cancer Research and Treatment 16 261-272.

McNatty KP, Makois A, DeGrozi C, Osothanondh R \& Ryan KJ 1979 The production of progesterone androgens and estrogens by granulosa cells, thecal tissue and stromal tissue from human ovaries in vitro. Fournal of Clinical Endocrinology and Metabolism 49 687-699.

McNeil M, Reed M, Beranek PA, Bonney RC, Ghilchik MW, Robinson DJ \& James VHT 1986 A comparison of the in vivo uptake and metabolism of $\left[{ }^{3} \mathrm{H}\right]$ estrone and $\left[{ }^{3} \mathrm{H}\right]$ estradiol by normal breast and breast tumor tissues in postmenopausal women. International Fournal of Cancer 38 193-196.

Martel C, Rhéaume E, Takahashi M, Trudel C, Couet J, Luu-The V, Simard J \& Labrie F 1992 Distribution of $17 \beta$-hydroxysteroid dehydrogenase gene expression and activity in rat and human tissues. Fournal of Steroid Biochemistry and Molecular Biology 41 597-603.

Martel C, Melner MH, Gagné D, Simard J \& Labrie F 1994 Widespread tissue distribution of steroid sulfatase, $3 \beta$ hydroxysteroid dehydrogenase $/ \Delta 5-\Delta 4$ isomerase (3 $\beta-\mathrm{HSD})$, $17 \beta$-HSD $5 \alpha$-reductase and aromatase activities in the rhesus monkey. Molecular and Cellular Endocrinology 104 103-111.

Nokelainen P, Peltoketo H, Vihko R \& Vihko P 1998 Expression cloning of a novel estrogenic mouse 17 betahydroxysteroid dehydrogenase/17-ketosteroid reductase (m17 HSD7), previously described as a prolactin receptorassociated protein (PRAP) in rat. Molecular Endocrinology 12 1048-1059.

Nokelainen P, Peltoketo H, Mustonen M \& Vihko P 2000 Expression of mouse 17 beta-hydroxysteroid dehydrogenase/ 17-ketosteroid reductase type 7 in the ovary, uterus, and placenta: localization from implantation to late pregnancy. Endocrinology $141772-778$.

Pasqualini JR, Gelly C, Nguyen BL \& Vella C 1989 Importance of estrogen sulfates in breast cancer. Fournal of Steroid Biochemistry 34 155-163.

Peltoketo H, Isomaa V, Mäentausta O \& Vihko R 1988 Complete amino acid sequence of human placental $17 \beta$ hydroxysteroid dehydrogenase deduced from cDNA. FEBS Letters 239 73-77.

Peltoketo H, Isomaa V \& Vihko R 1992 Genomic organization and DNA sequences of human $17 \beta$-hydroxysteroid dehydrogenase genes and flanking regions: localization of multiple Alu sequences and putative cis-acting elements. European Fournal of Biochemistry 209 459-466.

Peltoketo H, Nokelainen P, Piao YS, Vihko R \& Vihko P 1999 Two 17 beta-hydroxysteroid dehydrogenases (17 $\beta$ HSDs) of estradiol biosynthesis: $17 \beta$ HSD type 1 and type 7 . Fournal of Steroid Biochemistry and Molecular Biology 69 $431-439$

Poulin R \& Labrie F 1986 Stimulation of cell proliferation and estrogenic response by adrenal $C 19-\Delta 5$-steroids in the ZR-75-1 human breast cancer cell line. Cancer Research 46 4933-4937.
Poulin R, Baker D \& Labrie F 1988 Androgens inhibit basal and estrogen-induced cell proliferation in the ZR-75-1 human breast cancer cell line. Breast Cancer Research and Treatment 12 213-225.

Poulin R, Mérand Y, Poirier D, Lévesque C, Dufour JM \& Labrie F 1989 Antiestrogenic properties of keoxifene, trans-4-hydroxytamoxifen and ICI 164384, a new steroidal antiestrogen, in ZR-75-1 human breast cancer cells. Breast Cancer Research and Treatment 14 65-76.

Poutanen M, Isomaa V, Kainulainen K \& Vihko R 1990 Progestin induction of $17 \beta$-hydroxysteroid dehydrogenase enzyme protein in the T-47D human breast cancer cell line. International fournal of Cancer 46 879-901.

Poutanen M, Moncharmont B \& Vihko R 1992 17ßhydroxysteroid dehydrogenase gene expression in human breast cancer cells: regulation of expression by a progestin. Cancer Research 52 290-294.

Prostate Cancer Triallists' Collaborative Group 2000 Maximum androgen blockade in advanced prostate cancer: an overview of the randomized trials. Lancet 355 1491-1498.

Purohit A, Wang DY, Ghilchik MW \& Reed MJ 1996 Regulation of aromatase and sulphatase in breast tumours cells. Fournal of Endocrinology 150 (Suppl) S65-S71.

Recchione C, Ventrurelli E, Manzari A, Cavalleri A, Martinetti A \& Secreto G 1995 Testosterone, dihydrotestosterone and estradiol levels in portmenopausal breast cancer tissue. Fournal of Steroid Biochemistry 52 541-546.

Reed MJ \& Purohit A 1997 Breast cancer and the role of cytokines in regulating estrogen synthesis: an emerging hypothesis. Endocrine Reviews 18 701-715.

Serve H, Oelmann E, Herweg A, Oberberg D, Serve S, Reufi B, Mucke C, Minty A, Thiel E \& Berdel WE 1996 Inhibition of proliferation and clonal growth of human breast cancer cells by interleukin 13. Cancer Research 56 3583-3588.

Simard J, Durocher F, Mébarki F, Turgeon C, Sanchez R, Labrie Y, Couet J, Trudel C, Rhéaume E, Morel Y, Luu-The V \& Labrie F 1996 Molecular biology and genetics of the $3 \beta$-hydroxysteroid dehydrogenase $/ \Delta 5-\Delta 4$ isomerase gene family. Fournal of Endocrinology 150 S189-S207.

Simpson ER, Michael MD, Agarwal VR, Hinshelwood NM, Bulun SE \& Zhao Y 1997 Expression of the CYP19 (aromatase) gene, an unusual case of alternative promoter usage. FASEB Fournal 11 29-36.

Stewart PM \& Sheppard MC 1992 Novel aspects of hormone action: intracellular ligand supply and its control by a series of tissue-specific enzymes. Molecular and Cellular Endocrinology 83 C13-C18.

Tait GH, Newton CJ, Reed MJ \& James VH 1989 Multiple form of $17 \beta$-hydroxysteroid oxidoreductase in human breast tissue. Molecular Endocrinology 2 71-80.

Tamm I, Cardinale I, Krueger J, Murphy JS, May LT \& Sehgal PB 1989 Interleukin 6 decreases cell-cell association and increases motility of ductal breast carcinoma cells. Fournal of Experimental Medicine 170 1649-1669.

Tamm I, Cardinale I \& Murphy JS 1991 Decreased adherence of interleukin 6-treated breast carcinoma cells can lead to separation from neighbors after mitosis. PNAS 88 4414-4418.

Toi M, Bicknell R \& Harris AL 1992 Inhibition of colon and breast carcinoma cell growth by interleukin-4. Cancer Research 52 275-279.

Turgeon C, Gingras S, Carrière MC, Blais Y, Labrie F \& Simard J 1998 Regulation of sex steroid formation by interleukin- 4 and interleukin-6 in breast cancer cells. Fournal of Steroid Biochemistry and Molecular Biology 65 151-162.

Van Landedgem AAJ, Poortman J, Nabuurs M \& Thijssen JHH 1985 Endogenous concentrations and subcellular distribution of estrogens in normal and malignant human breast cancer tissues. Cancer Research 45 2900-2906. 
Vermeulen A, Deslypere JP, Paridaens R, Leclercq G, Roy F \& Heuson JC 1986 Aromatase, 17 $\beta$-hydroxysteroid dehydrogenase and intratissular sex hormone concentrations in cancerous and normal glandular breast tissue in postmenopausal women. European Fournal of Cancer and Clinical Oncology 22 515-525.

Whitford P, Mallon EA, George WD \& Campbell AM 1990 Flow cytometric analysis of tumour infiltrating lymphocytes in breast cancer. British Fournal of Cancer 62 971-975.

Wu L, Einstein M, Geissler WM, Chan KH, Elliston KO \& Andersson S 1993 Expression cloning and characterization of human $17 \beta$-hydroxysteroid dehydrogenase type 2 , a microsomal enzyme possessing $20 \alpha$-hydroxysteroid dehydrogenase activity. Fournal of Biological Chemistry 268 12964-12969.
Zhao Y, Nichols JE, Bulun SE, Mendelson CR \& Simpson ER 1995 Aromatase P450 gene expression in human adipose tissue. Role of a Jak/STAT pathway in regulation of the adipose-specific promoter. Fournal of Biological Chemistry 270 16449-16457.

Zhorov BS \& Lin SX 2000 Monte Carlo-minimized energy profile of estradiol in the ligand-binding tunnel of 17 beta-hydroxysteroid dehydrogenase: atomic mechanisms of steroid recognition. Proteins 38 414-427.

Zhu DW, Lee X, Breton R, Ghosh D, Pangborn W, Duax W \& Lin SX 1993 Crystallization and preliminary X-ray diffraction analysis of the complex of human placental $17 \beta$-hydroxysteroid dehydrogenase with NADP+. Fournal of Molecular Biology 234 242-244.

RECEIVED 14 March 2000 